\title{
Persistence in present-day Cultural practice OF TRADITIONAL (RABBINIC) ONOMASTIC WORDPLAY. THE CASE OF STANDING UP TO SYSTEMIC INFERIORISING ATTEMPTS, ON BEHALF OF ONE'S COLLECTIVE SELF
}

\author{
EPHRAIM NisSAN \\ London, England
}

\begin{abstract}
Onomastic wordplay is a conspicuous device in early rabbinic homiletics (the Aggadic Midrash) from late antiquity. Novel onomastic wordplay has been occurring in the early modern period, and even (in a polemical context) at present. We develop in depth a current case study involving onomastic wordplay redeploying such devices from within the given culture. Arguably, this onomastic practice can still be psychologically poignant, in that it has a consolatory function as a display of vicarious empowerment even in what are sometimes otherwise dispiriting situations of powerlessness. In the penultimate section of this paper, we are going to exemplify enough technical details of onomastic resemantisation in line with the ancient tradition but as applied to a current situation, as to show the algorithmic structure of the process of making the potential of alternative interpretations come to fruition.
\end{abstract}

Keywords: midrashic derivations of personal names, rabbinic homiletics, wordplay, resemantisation, current affairs (Britain), legal history, controversies, antisemitism.

\section{Introduction}

Onomastic wordplay already frequently occurs in the Hebrew Bible (Garsiel 1991). This cultural practice took on a different form in late antique (Roman-age) rabbinic homiletics within Bible exegesis. Rabbinic wordplay is the subject of EilbergSchwartz (2004). Elsewhere (Nissan 2012, 2014a, 2016; Nissan and HaCohen-Kerner 2014a, 2014b) I have shown that in a literary context, the devices of rabbinic onomastic homiletics, with its stylemes and other patterns, can still be employed in a given literary genre. In Garsiel's book (1991) about onomastic wordplay in the Hebrew Bible, within Sec. 7.3, "Three Theories Concerning the Formation of MNDs" (i.e., of Midrashic Name Derivations), in \$7.3.1, “The Hypothesis of Invented Symbolic Names”, Garsiel (1991: 259) mentioned how some modern scholars "more than once suggested that names associated with MNDs are literary names (charactonyms) given to figures in a narrative to correspond with their deeds". Garsiel's $\$ 7.3 .1$ and $\$ 7.3 .2$ respectively are "The Hypothesis of the MND as a Factor in Story Creation", and "The Hypothesis of the Authors' Literary Skills". Garsiel favours the latter (and so do I). The author's skills 
can overcome the need to change "one or the other side of the midrashic equation either in the name, as in the first hypothesis, or in the narrative materials" (1991:265). In a sense, the best evidence in support of this hypothesis would be showing that given a real-life situation from the present time, one may homiletically interpret in Hebrew the personal names of some of the principals, and that the homiletic sense thus yielded would befit the narrative situation at hand. We set to do that in this paper.

King Lear: present-day literary creativity, midrashic style, and charactonyms

Onomastic wordplay as familiar from late antique or medieval rabbinic homiletics (in the early and late Midrashim) can still be marshalled in a given archaistic literary genre. Apart from my scholarly research, I am also a literary author when I find the time for that, and I have tried, successfully I think, to show that it is still possible to contrive both a storyworld and a style in that tradition. Consider a one-paragraph (allegorical) transposition of Shakespeare's King Lear, of 30 July 2017 (7 Av 5777), minimising both the set of characters (reduced to just Lear and his daughters), and the action. The charactonyms are aetiologised by punning in any of three categories: phonetic, graphemic (exploiting features of the script), or morphological (posturing as though the source and the target words were co-derivatives). The name of each of Lear's daughters is interpreted twice: positively, then negatively.

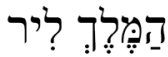

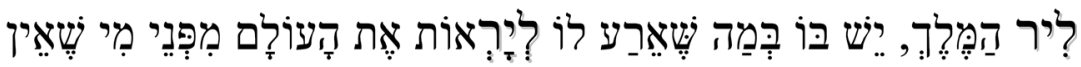

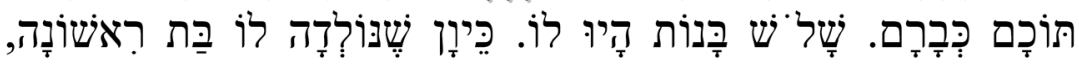

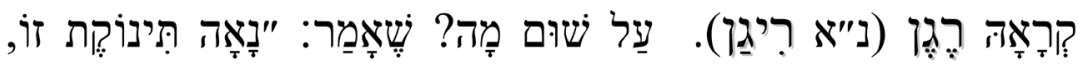

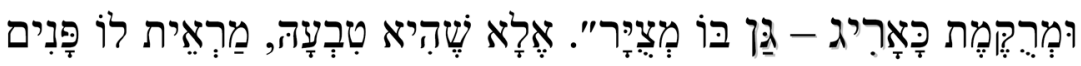

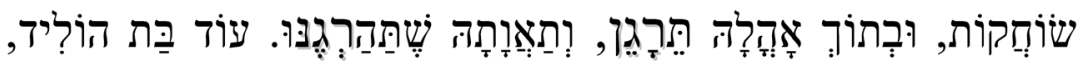

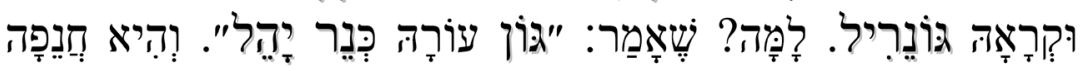

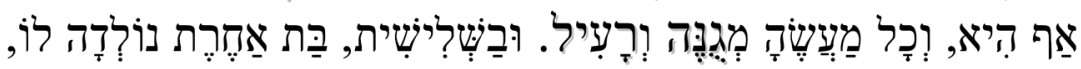

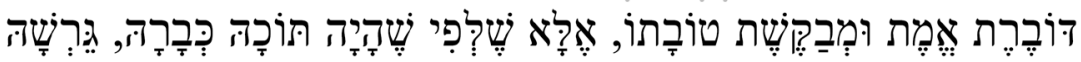

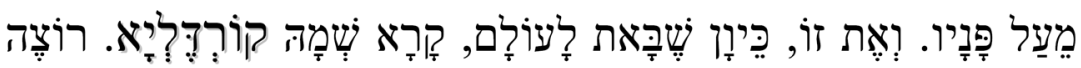

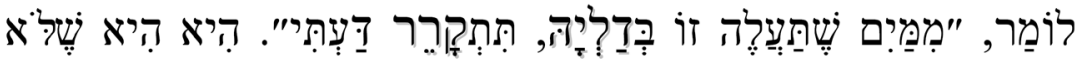

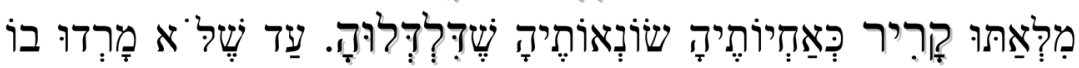

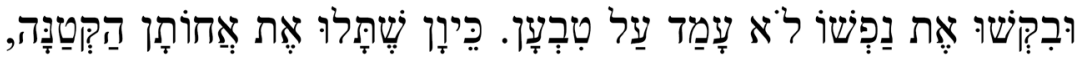

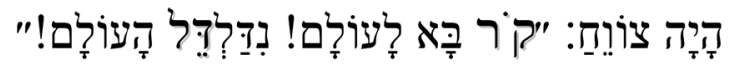

King Lear 
King Lear $\langle\mathbf{l y r}\rangle$, what happened to him has the potential to make the world afraid (leyar'ót, <lyr'wt>) of such whose inside is not like their outside. He had three daughters. As a first daughter was born to him, he called her Régen <rgn> (var. Rigan [= Regan]). ${ }^{1}$ Why so? As he said: "This baby, she is cute, and embroidered like aríg, cloth (tapestry) depicting a garden (gan)”. But she, her nature was such, that she would show him a smiling face, but inside her tent she was grumbling (teragén [cf. Deuteronomy 1:27: "and you grumbled in your tents"]), and she craved killing him (šetahargénnu $<$ šthRGNw>). He begot yet another daughter, and called her Goneril < gwnryl >. Why? As he said: "The colour of (gon, $\langle\mathbf{g w n}>$ ) her skin is like a candle (ner, $<\mathbf{n r}>$ ) shining (yahél, $<\mathbf{y h l}>$ )". She, too, was a flatterer, and everything she did was indecent and toxic (megunne vera'il, $<\mathbf{m g}[\mathbf{w}] \mathbf{n h} \mathbf{w r}^{\prime} \mathbf{y l}>$ ). The third time, another girl was born to him, one speaking truth and seeking his good, but as her inside was like her outside, he chased her from his presence. This was, once she was born, she called Cordelia $<$ qwrdly'>. To wit, "By the water she will lift in her bucket (dalyáh), I shall be becalmed (my mind shall be cooled (titqarér)". ${ }^{2}$ It was precisely she who did not deceive him (fill him with coolness (qarír) the way her sisters did, her haters who dildelúha (made her the poorer, or: hanged her limp). Until they rebelled against him and sought [to take] his life, he did not realise their nature. Once they hanged their youngest sister, ${ }^{3}$ he was shouting: "Cold (qor) has come into the world! The world niddaldél! (is now the poorer! Also: hanged!)”.

\section{In the background of the Fiery Furnace: Daniel's companions' interaction with Nebuchadnezzar in a rabbinic homily}

The Book of Daniel relates that King Nebuchadnezzar threw into a furnace three of Daniel's companions who had refused to conform to idolatry, and that they were saved miraculously. The moment when Nebuchadnezzar reacted angrily at their refusal is (as shown in Nissan 2014c) reimagined in a homily by shaping the event both by reference to how his name, Nebuchadnezzar, could be segmented, and arguably also by reference to another episode (when he lost his human reason and started to behave like an animal, only to be restored to reason and to his throne seven years afterwards. In a passage in Leviticus Rabbah 33:6, the question is asked: why does the verse which relates the three's refusal mention Nebuchadnezzar as "King Nebuchadnezzar", whereas either "the King" or "Nebuchadnezzar" would have sufficed? The answer given is that the three companions (the youths who were to survive the fiery fire) had told him - so the homily maintains - that for matters like taxation, he is the King and they would

1 Régen is an adaptation of the charactonym Regan to a Hebrew "segolate" noun pattern. Cf. the Italian adaptations Regana, Gonerilla. The name Regan is amenable, in Hebrew, to folketymology relating it to words denoting 'grumbling' or 'quarrelling.'

2 Cf. the Hebrew genitival phrase Qor-dalyah, 'the coolness of [the water in] her bucket'.

3 In Jewish hymnography, the "youngest sister" is the Jewish nation, allegorically after Song of Songs 8:8.

${ }_{4}$ The story of the three youths in the furnace, from Ch. 3 of Daniel, also had wide currency in Christian traditions. A medieval wall painting (with a detail) from a Nubian church, now on display at the Khartoum Museum, depicts the story of the three youths thrown into the furnace, with an angel. 
comply with his order, but when it comes to matters of worship, he is Nebuchadnezzar, and when it comes to an order for them to become renegades to their faith, they would not comply any more than they would do, if faced with a dog ("you and a dog are equal"): he could as well "bark (nebach) like a dog, be blown up (nepach) [distended] like a pitcher $(\underline{k} a d)$, and chirp (nezar) like a cricket. He [Nebuchadnezzar] immediately barked like a dog, was blown up like a pitcher, and chirped like a cricket". Which is how angry or almost apoplectic you could imagine a despotic king to become, on being challenged in the quite impertinent way described. (This way, the omen implied by the nomen became actualised once the person had been told how the name is to be interpreted.) Then, in the rest of the homily, ${ }^{5}$ a verse from Ecclesiastes is cited in support of one having to obey a king, but not to such an extent that one would spite one's Creator. Arguably the reference to the King making sounds like an animal is an allusion to his period of madness: a story which is also impertinently embellished, in a different homily.

\section{Recent and current turmoil}

For in much wisdom is much grief: and he that increaseth knowledge increaseth sorrow. Ecclesiastes 1:18, King James Version.

British current affairs come to the attention of the public in other Western countries are only to a quite limited extent, such as Brexit since 2016, or, in 2002, the launch from within vocal quarters in British academia of a boycott against Israelis (I, who live in London, have nearly 500 publications, and yet have been unsalaried for almost the entirety of the 21st century). One event in particular did receive attention on the European Continent: during the 2016 electoral campaign for the referendum on Brexit, a bright up and coming politician of the Labour Party, Jo Cox, a Member of Parliament (MP) for a constituency in the North of England, was murdered by a far rightist. The situation in her own party was out of the ordinary, since the party's takeover, in the previous autumn, by the far left, with a party within the party, Momentum, clamouring for the extromission (by deselection) of moderate Labour MPs. At a time

5 The passage is in Aramaic, close enough to Hebrew for the verbs for 'to bark' and 'to blow up' to occur with respectively identical lexical roots in both languages. As for the Aramaic verb netsar for 'to chirr', 'to chirp', as applied to the cricket (Tannaitic Hebrew tsartsúr, Modern Hebrew tsratsár), in Tannaitic Hebrew it occurs once, and then as denoting making sounds as associated with another animal kind, pigs: the participle noser [in] in that sense occurs in the Mekhilta de-Rabbi Ishmael - but then not in all versions: it does occur in the Lauterbach edition - within a sentence addressing a character used to eat pork: "Pigs are grunting from between your teeth" [i.e., it is known you eat them] (see s.v. $n \mathbf{s} r_{2}$ in Moreshet 1980). The initial part of the personal name Nevukhadnétsar matches the Hebrew phrase nafúa he-khád 'blown-up/distended/pot-bellied like a pitcher', as well as the mixed Hebrew and Aramaic phrase (but you could make it fully Aramaic) navóạ ke-"ḥad [kalba]", i.e., "to bark like [Aramaic:] 'one dog”"; $\boldsymbol{h}$ ad kalba is how the homily's text words its equating that king to a dog. 
in British modern history when the country's brightest and more credible politicians in both main parties appear to be women, also another phenomenon emerged: burly activists (often in the trade unions) hugely resenting the position women have carved out for themselves in politics. Since Jo Cox's assassination, several Labour women politicians have been receiving threats, from both the far right and far left, a frequent threat being that they will be killed like Jo Cox. Sometimes, such threats have included a neologism: "You'll be coxed" (rather than a threat of the recipient going to be killed "like Jo Cox", which has been apparently occurring more frequently). I don't know whether the neologised verb will enter the Oxford English Dictionary. It certainly deserves notice in onomastics scholarship. With the surge in overt antisemitism, partly in concomitance with the surge of the far left, the two phenomena have merged in the case of Jewish women MPs within Labour who have been subjected to intensive abuse, in part by trolls, but in part even in the presence of the party's leader. ${ }^{6}$

\section{On some developments within the judiciary}

The following case study of a complex - and distressful - human situation and its onomastic culture-bound subjective responses is a turn that a previous phase of this writing project this article took because of very worrying juridical and judiciary developments in Britain in the spring and summer of 2017. The wide public perceived that period as an electoral roller-coaster, followed with an uninspiring humdrum of Brexit negotiations and other indignities. My concern instead is with how the campaign started in 2002 to disenfranchise my group identity, and which spread unopposed in

6 And that at the launch of the report (the Chakrabarti report) of an inquiry about the surge of antisemitism in the party, a report that disappointingly was a whitewash. An activist who in the room lashed with charges of treason at a Ruth Smeeth, a Jewish Labour MP who left in tears, was shortly afterwards photographed with the party's leader laughing. By late September 2016, Ruth Smeeth had received 25,000 threats. There is one woman MP who has been abused by Internet trolls even more massively (45,000 times) than the Jewish women MPs in the party: Diane Abbott, a far left staunch supporter of the party leader, and one who infamously referred to Jewish concerns and misgivings about the new leader as "anti-Semitic smears". Smeeth identifies herself as Jewish (because her mother is), whereas Abbott is Black. That in this couple of years, women, Jews, and Blacks have been targeted as described has a clear precedent in the 19th century (Gilman 1984), when the Jews having obtained emancipation in the West, Blacks having been freed from slavery in the United States, and women seeking equal rights were subjected to hostile rhetoric ascribing madness to all three, hysteria in the case of women, derangement being ascribed to Black people as though it was caused by not being slaves, and Jews being ascribed congenital mental illness as a new version of the old trope of ascribed melancholia or even male menstruation (Nissan and Shemesh 2010). Otto Weininger was an infamous thinker who reasoned likewise about women and Jews (Harrowitz and Hyams 1995). Claiming, to say it in plain words, that the Israelis are crazy while burdening them with utter wrongs is something that a professor in London, Jacqueline Rose (2005), has tried to do in a book published by Princeton, and aptly criticised by Shalom Lappin (2009). More often, the goal is proclaimed of making pariahs out of Israelis, which incidentally shows also utter contempt for the Dalit/ Paryar/Untouchable people of India. 
British society by illegal means until scandalously endorsed by an industrial tribunal in 2013 (in Fraser v UCU), has now attained endorsement within part of the very elite of the judiciary. First, in a legal opinion (Sedley 2017) so that a very belated step of the U.K. government intended to stem anti-Semitic initiatives and climates in institutional settings be thwarted (and this from an author, Sir Stephen Sedley, who is a knighted retired senior judge and with a flurry of honorary doctorates), and then in the High Court ruling against central government so that local government be not hindered when adopting boycott initiatives. Lady Sedley was one of the three members of the tribunal that ruled in Fraser $v$ UCU, and that in April 2017 Sir Stephen has reportedly being a guest at the House of Lords in order to sedulously support a legal opinion by Hugh Tomlinson, commissioned by a set of organisations engaged in a furore of propaganda that Jews deeply resent and fear, in order to thwart efforts to stem in antisemitism in British society, is just one element that smacks of irregularity, and that is precisely the kind of hatemongering ebullience that Fraser $v U C U$ was brought in order to try and rein in academia (specifically, in the lecturers' union, where it is a regular fixture), and that the tribunal thwarted: an outcome that caused astonishment even to legal experts. ${ }^{7}$

A High Court ruling on 22 June 2017 has delegated to local government in Britain (contra central government) the "right" to boycott what is my national identity by birth. This deserves all the more opprobrium, as it reintroduces into Europe a juridical state of affairs from before the emancipation of the Jews: the state is turned into a spotted leopard skin, where sundry local authorities flatter themselves by instituting harsher measures of Jewish exclusion (it used to be the cities' privilege de non tolerandi Judaeos). While Britain is the throes of Brexit, the High Court ruling does for the

7 According to a report unveiled in August 2017, 70\% of British Jews feel unwelcome to Britain, owing to anti-Semitism and (the state's, the parties', and the institutions') failure to tackle with it. In 2015-2017, considerable Jewish emigration from Britain was noticed. Whereas from 2002 there has been an upsurge in antisemitism in Britain, encompassing the new century thus far and involving vociferous exclusionary precepts in initiatives undertaken within professional associations or trade unions, as well as in academia, the 2010s have been remarkable in how rung above rung in the ladder of the courts of justice echelons, judicial opinions and rulings have made it their task to protect the supposed right of perpetrators to carry on with the persecution. I personally find this especially disturbing, as being the author of 500 scholarly publications, yet one who after a horrific ordeal in 2002-2004 on racial grounds at an academic institution has almost held no salaried position since, as well as a scholar who has devoted thirty years to research into an interdisciplinary domain encompassing law (e.g., Nissan 2012b), and moreover as one whose family background (only being born because my mother did not perish in a massacre in Baghdad on 1-2 June 1941, taking place under the heartlessly impassive eye of the British army being present) belies the factoids taken for granted by those receptive to hostile propaganda. I am in mourning at the state of the British justice system, as well as at the depth of the British crisis. This is a society that for generations has had a problem with antisemitism. During this century, is has been promoted here as though as it was a virtue, especially by a legion of academics. 
U.K. the opposite of what President Kennedy did for the U.S. by desegregating federally. He did it because of the damage race segregation was doing to the U.S. in the Cold War. But Britain, because of Brexit no longer in need, it seems, not to violate European law, still needs a dignified co-existence with the rest of humankind, including formerly colonised peoples. Yet, racism here is rife and complacently tolerated.

In the rest of this study, we are going to consider how Jewish onomastic homiletics still persists sometimes as an individual's cultural practice, serving the need to stand up to systemic attempts to inferiorise one's collective as well as individual Self.

\section{Surnames and identity}

The legal opinion written by Hugh Tomlinson, a lawyer instructed by anti-Israel activist groups (including groups whose very name claims Jewish ancestry for their respective members, but actually typically Trotskyites or Stalinists) - and quite importantly, organisations whose membership, as shown by David Collier in a numbers of reports, ${ }^{8}$ includes a flurry of prominent members, overwhelmingly native Britons, who double as conspiracy-theorists endorsing on the Web grotesque claims about the Jews - was launched at the House of Lords by Sir Stephen Sedley and Sir Geoffrey Bindman. This partly clarifies who are the supposed Jews who, Sedley (2017) proclaims, oppose Jews' national rights (as embodied by Israel) and in Sedley's opinion (2017) must be heeded, contra the stance of the other Jews, namely, the stance shared by the great majority of Diaspora Jews who do cling to Jewish identity. It may be that Sir Stephen was swayed by the opinions of his late father, a lifelong Communist according to the son's Wikipedia page, and that he is not fully cognisant of the cultural dynamics involved. Bindman, too, has Jewish ancestry. (The surname Sedley belongs to native English onomastics. For example, "But let no alien S-dl-y interpose", John Dryden wrote in his 1682 poem Macflecknoe, v. 163, satirising an author who would not learn from Sedley.)

The end of the Soviet Union had some results in radical circles in the West. One of these was that internationalists turned to boutique causes, no longer bothering to endorse an array of "progressive" causes (Julius 2010). This made it more respectable, as though, for individuals and groups to focus on just one cause, such as delenda Israel..$^{9}$ Besides, whereas Communist families who had Jewish ancestry had often long shunned that identification, the post-Communist way of thinking encouraged people to embrace ethnic identities. This in turn resulted in groups that only claim for their members Jewish ancestry in order to deny Jews their national rights, or in order to advocate an apocalypse for Israel and her populace. The Jewish British writer Howard

\footnotetext{
$8 \quad$ E.g., http://david-collier.com/wp-content/uploads/2017/02/170222_palestine_solidarity_campaign_report.pdf (accessed in May 2017).

9 Russia no longer being an enemy to Israel shook the confidence of some in the West that Israel would be destroyed, so they intensified their hostility, taking it upon themselves to see to it that it would come to pass. They only need the Palestinian Arabs as cannon fodder, and would consider themselves betrayed if there is peace.
} 
Jacobsen satirised this phenomenon in his novel The Finkler Question, both comic and sad, which won the Booker Prize in 2010: an old man comes to believe he is Jewish, so he joins ASHamed, an organisation agitating against Israel. ${ }^{10}$

One thing that distinguishes human beings from beasts is that beasts are better, in that they are unable to develop racial hatred towards a given human group, even though, it must be said, horses being prone to nervousness, some horses are not unknown to react with fright if seeing a human being whose skin colour they never saw before, and dogs, too, may become aggressive. But no animal kind brings to Jews' minds as sad memories, as much dismay, as Dobermanns, as these were deployed by

10 It is important to realise that whereas it used to be a pattern for centuries that some converts be made use of against their Jewish former co-religionists, onomastically the names of converts used to be changed, and for example in Rome still by the mid-19th century often members of the nobility would give their surname to converts. Family names were only systematically imposed in Europe upon Jews in the late 18th and 19th centuries. Such family names were often retained by families that by the early 20th century had overtly abandoned Judaism. There was a pattern of men on America-bound ships who threw into the sea their phylacteries bag, a symbolic watershed indicating that they were unwilling to identify in America with the identity because of which they had suffered in the old country. There also were adepts at radical ideologies, political religions indeed, such as the anarchists, some of whom in New York City were not above throwing pork products at Jews going to the synagogue during the High Holidays. There was a determining factor which caused such Jewish-born members of revolutionary Left to turn against the other Jews: in accordance with the doctrine of internationalism and class struggle, they claimed to side with the international proletariat, and that they fought the bourgeoisie, and within Jews, the Jewish bourgeoisie, as well as reactionaries (i.e., anybody who thought differently from them, and this included observant Jews). The problem was that the chimaera called "international proletariat" not infrequently turned against the Jews. In one such instance, the 1881 pogroms in the tsarist empire were inspired by the far right (a riot erupted in 1881 also in Jerusalem, along with a blood libel). A revolutionary who was born into a Jewish family but had formally converted to Russian Orthodoxy (probably to be freed of civil disabilities) applauded the 1881 pogroms in a printed manifesto. For decades, Russia's far left denied the existence of that manifesto (a photograph was reproduced in one of the early volumes of the Encyclopaedia Hebraica). By 1929 however Communism had become unfazed about collusion with the far right.

Following the massacres suffered by the Jews in Palestine in the summer of 1929 (especially targeting cities with centuries-old Jewish communities - e.g., Gaza's Jews survived by fleeing as well as wiping out some small farmer communities), responses on both the far right and far left involved: (a) In Romania in 1929, the most extreme campaigners for the abolition of the rights of local Jews - the Legion of the Archangel Michael, the future Iron Guard - also campaigned specifically (through the Ad Hoc Committee for Positive Arab Propaganda set up by the Legion) in favour of the perpetrators of those same atrocities, and in so doing were invoking religious arguments (Armon 2005: 124, fn. 43). (b) In Italy, the clerical press gloated. (c) In Moscow, the Comintern endorsed the perpetrators of the massacres, considering them revolutionaries (they were clericals instead), and required Communists of Jewish extraction worldwide to display enmity to Palestine's Jews (Hen-Tov 2012 [1974]). One instance of infamous compliance of local Communists was in New York. Non-Jewish Communists in Germany (most of them later Nazified) aligned themselves eagerly with that Comintern order. 
the Nazis at concentration and extermination camps against inmates. Now, consider the following exercise, a Gedankenexperiment, and let it be clear that I utterly disapprove of the proposition it reasons about metalinguistically; it is only being used here for illustration purposes. Doberman is the surname of the mother of the lawyer Geoffrey Lionel Bindman (he was born in Newcastle in 1933). If anybody were to state than now antisemites have turned to unleashing a Half Doberman against a vital matter at the heart of Britain's Jewish community, Bindman would be quite justified howling that the Holocaust is being used against him. Why then is it OK to blame Israelis for being Nazis, while the only rationale for doing so is that it is the charge a Jew would find most horrid $?^{11}$ And yet, that charge is common fare in anti-Israel discourse, and for example in September 2017 a British Jewish university student, one who admitted he knew very little about Judaism, but one to whom his Jewishness matters, wrote in the Jewish Chronicle that when he said he is interested in journalism, other students stared at each other (the reason was left implicit: they subscribe to the canard that the Jews control the media), and that one student, upon learning he was Jewish, asked him about "that Nazi Netanyahu killing Palestinian children". Shortly after in 2002 the boycott against Israeli academics was launched by an unfortunate mob here in Britain, it was reported in an Israeli newspaper that a Jewish British lecturer (who kept his anonymity, presumably to avoid becoming forever unemployable in the U.K.) who had been in visit in Israel, phoned a British university department to which he had applied for a job, and a manager snarled back that they get nobody from a Nazi country.

\section{Exeter - Iscä - “We've made a deal!”}

There is a fascinating phenomenon: Britain as a refugium peccatorum, if you will, in the sense that one is left with the impression that in no other country does one find so high a concentration, especially in academia, of persons claiming Jewish ancestry but vocally inimical to Jewish national rights (this may be a factor in Sedley's mistakes), and more specifically of such persons who are Israeli expatriates with such a Left-wing identity that finds Jewish national rights repugnant. They may be a number of factors for this: a historical grudge in the U.K. against Israel being born notwithstanding Britain's efforts to smother her at birth contrary to the U.K.'s undertaken international obligations; the U.K. being a magnet to members of peoples formerly under U.K. rule; and a spectrum of academic employers' attitudes, ranging from ones indifferent to (or tolerant of) such vocal activism, to ones motivated to hire precisely by that activism of the job seeker. The latter is certainly the case of such academic departments that on

11 The genealogy of that charge is known. It was made by John Bagot Glubb, the commander of the (Anglo-)Arab Legion of the Emirate of Transjordan, the army that (with the blessing of the Foreign office in London), attacked the State of Israel at its birth, and was the most successful of the five invading armies. That charge was then made by Arnold Toynbee, and popularised afterwards. A historiosopher (which Toynbee was) is to a real historian what an astrologer is to an astronomer. Historiosophy is charlatanry. Astrology instead was a science once upon a time. 
record have been breeding such hostility. ${ }^{12}$ One such department that springs to one's mind is in Exeter, which affords a pun - "We've made a deal!" - in that the city's ancient name was Iscā, which happens to sound like the Talmudic Aramaic noun 'isqā for 'deal'. Ilan Pappé went there.

As for the real background of the toponym: "Iscā, a British [pre-Roman] rivername on which see RN [= Ekwall 1928, pp.] 151-6, is the source of Esk", that river's current name (Armstrong et al. 1952: 480, s.v.). Old names for Exeter include "I $\sigma \kappa \alpha$ in Ptolemy (c. 150 C.E.), the city being named after its river; Isca Dumnoniorum in the Roman Tabula Peutingeriana; Isca Dumnuniorum in the Antonine Itinerary (Itinerarium Antonini Augusti); Isca Dumnamorum in the Ravenna Geographer (Ravennatis anonymi Cosmographia, c. 650); Adescancastre in the Vita Sancti Bonifacii (c. 750); Exancaaster for example on Alfred coins; Essecestra in 1086 (in the Exeter copy of the Domesday Book); and so forth. The earliest known record of form Exeter is from 1547 (Gover et al. 1969: 20-21).

\section{An episode in the campaign against the British government's adopted definition of antisemitism}

Ceci n'est pas un festschrift Part of the subtitle of a Festschrift (Probst 2005).

In my own research, which over the years has also combined artificial intelligence and the generation of creative explanations, I have often found that the odds are high that given enough skill, you can bridge a name and a concept by means of a narrative trajectory. ${ }^{13}$ But sometimes a real name and a real situation can be fitted by folk-etymology. For example, I am now writing on 5 May 2017. During early May I was mightily distraught (and by the autumn had not yet recovered my peace of mind) upon reading in the radical chic London Review of Books an article, entitled "Defining Anti-Semitism" (on what is or is not antisemitism) and authored by the influential former High Court and Court of Appeal judge Sir Stephen Sedley (Sedley 2017). Born in 1939, he usually writes for the London Review of Books learned, elegant legal analyses of various topics. (This is in addition to his judicial opinions being influential with the judiciary.) This time instead he wrote an outwardly elegant and even-headed but chilling call upon

12 Until a few years ago, but perhaps not at present, foreign policy makers may have considered it an asset that there be here a hotbed of destabilisation for given former colonies, as though it could offer leverage to U.K. policies. I am also asking myself whether a contributing factor may not have been the early modern phenomenon, in the strife between Protestant and Catholic intellectuals, of such defectors to a country in the hands of the other side, with some of them apparently gladly wishing the pox on their former fellow nationals for belonging to the "wrong" faith. Apostates from Judaism instead had not as showy a role, yet nevertheless had a role, in British academia in the 19th century and earlier; a medieval case was a man who came from Spain to England, Peter Alphonsi, the author of the famous Disciplina clericalis.

13 Nissan (2012a, 2014c, 2016); Nissan and HaCohen-Kerner (2014a, 2014b). Cf. Nissan (2013a). 
judges and university managers not to accept the definition of antisemitism adopted at long last by the British government (a belated, insufficient response to the climate that has made antisemitism in Britain the new normal from the beginning of the 21th century to the present). He points out that policy is not law, and that using that definition of antisemitism may be even unlawful.

Arguably, Sedley (2017) contradicts its second sentence: "Where it manifests itself in discriminatory acts or inflammatory speech it is generally illegal, lying beyond the bounds of freedom of speech and of action". This is contradicted by his specifically singling out such egregious examples that are (not only in speech or written text, but even architectonically and in carol lyrics: carols demonising Israel, and a wall built in front of the façade in order to make Israel hateful to the faithful or even passers-by) inflammatory and contribute precisely to Britain's now notorious practice of discrimination. We are not merely talking about potential for incitement and race discrimination. This has already taken place, and we have been experiencing this for a long time. Much in what is advocated in Sedley (2017) is completely at odds with his (lip-service?) exclusion of "discriminatory acts or inflammatory speech". The entire enterprise (it has been called a "tsunami") of trying to bring down the definition of antisemitism adopted by the U.K. government in December 2016 is certainly intended to protect perpetrators who make Jews' life here (and have made mine) miserable.

Curiously, Sedley (2017) is uninterested in the categories of truth and untruth. What he claims antisemitism is, disregards that claiming about Jews (or then about the country with their highest concentration) something that they are not or that they do not. In fact, since at least the Middle Ages to the Holocaust and to the present time, it was central to the Western (and in recent generations, by ideological syncretism, also Middle Eastern) tradition of antisemitism to develop a miasma of falsehood, seeking corroboration through obsessive self-referencing, i.e., citing its own echo chamber: it is quite telling that Sedley invokes Robert Falk as a supposedly authoritative voice, a "leading American scholar". ${ }^{14}$ For example, this has been quite evident in the promo-

14 See https://en.wikipedia.org/wiki/Richard_A._Falk - Falk was born in 1930. In 2008, the United Nations Human Rights Council (UNHRC) appointed Falk to a six-year term as a United Nations Special Rapporteur on "the situation of human rights in the Palestinian territories occupied since 1967”. In 2013: “The European representative said 'The EU continues to regret the unbalanced mandate of the Special Rapporteur and is also concerned that parts of the report include political considerations. In the past, the EU emphasized that future reports should be based on a more factual and legal analysis, and we regret to see no genuine progress in that direction. The council needs to be provided with accurate, factual information and solid allegations to fulfill its role and address the human rights situation in occupied Palestinian territory'. The United States Ambassador to the UNHRC, Eileen Donahoe, called for Falk's resignation, saying 'Falk's attack on UN Watch threatens the independent voice of civil society at the UN. NGO work is particularly important in the field of human rights. Mr. Falk's most recent statement - which he dramatically and recklessly included in an official UN document is characteristic of previous reprehensible comments and actions he has made during his tenure as a special rapporteur. His views and behavior, both official and unofficial, are offensive and 
tion of blood libels (a category that, when broadly meant, also includes, e.g., the charge of well-poisoning). The effects of generating and maintaining a miasma of false charges against Jews has historically been to transform the people into a rabid mob, the courts into travesty, and both into killing machines.

Careful reading of Sedley (2017) shows that when he drops names of individuals, places, or events, he contradicts glaringly the exclusion he states early on of "discriminatory acts or inflammatory speech". He blames British Jews for opposing Falk giving a speech, but it was precisely because Falk is extremely inflammatory. Britain's Stop the War far-left organisation (whose primary aim was to oppose Western intervention in Afghanistan and Iraq) has long posted on its website a call by Falk for war against Israel (Sugarman 2017a). I saw a similar call in a neo-Nazi poster I saw in Rome in 2010 (when in a taxi, sent by a law conference in Camerino to take me there as an invited speaker with a Cassations judge). Stop the War only removed Falk's call for war in preparation for a senior member of its becoming a senior electoral agent of Labour's current leader, long associated with Stop the War.

Sedley (2017) takes a different route, but his method of deflecting a commendable if not necessarily quite word-perfect definition of antisemitism, adopted after fifteen years of delay by the British government in order to start to stem a phenomenon that has been becoming pervasive, to my mind has an affinity for something I have used as an epigraph: Ceci n'est pas un festschrift, which is part of the subtitle of a Festschrift celebrating a scholar (Probst 2005). Denying that something is X, even though it is ostensibly X.

"If you fail to accept that antisemitism can morph into anti-Zionism, you enter the

provocative and do nothing to advance peace in the Middle East or to further the protection and promotion of human rights. We again call for his resignation". Falk has also become notorious as a conspiracy-theorist trying to blame "neoconservatives" (notoriously a code name for American Jews) for the September the 11th attacks; in fact, in 2008 Falk stated: "It is possibly true that especially the neoconservatives thought there was a situation in the country and in the world where something had to happen to wake up the American people. Whether they are innocent about the contention that they made that something happen or not, I don't think we can answer definitively at this point”'. Moreover: "In April 2008 Falk compared Israeli actions in Gaza to those of the Nazis". Falk has Jewish ancestry, but his parents saw to it he would be estranged to Jewishness; perhaps even the middle name Anderson was a means to that end.

Falk even managed to add his own antisemitism as an ingredient of statements of his about the Boston Marathon bombings. "Canadian Foreign Minister John Baird sharply criticized Falk, stating that 'Once again, United Nations official Richard Falk has spewed more mean-spirited, anti-Semitic rhetoric, this time blaming the attacks in Boston on President Obama and the State of Israel. The United Nations should be ashamed to even be associated with such an individual. The United Kingdom, in a statement by its UN mission, noted that this was 'the third time we have had cause to express our concerns about Mr. Falk's anti-Semitic remarks. It is important to the U.K. that special rapporteurs uphold the highest standards in their work and we have twice previously made clear that remarks by Mr. Falk were unacceptable. United Nations Secretary General Ban Ki-moon rejected Falk's statements, saying that they undermined the credibility and work of the UN". 
world of the absurd. Why on earth wouldn't it? If like Stephen Sedley you remove 'Israel as Jew' almost entirely from the equation, then you blatantly fail to protect Jews from those that hate them" (Collier 2017a). Considerable regard is shown in Sedley (2017) to the claim that Jews are not a people or (note the deft equivocation on the sense from legal jargon) "race" (and that claiming that they are a "race" would be claiming the same as what antisemites claim), that it is improper to claim that Jews have national self-determination rights because (he claims) many Diaspora Jews (former Jews?) deny that the Jews have them, and that moreover Israel is incomparably, indeed uniquely ${ }^{15}$, illegitimate in regard of how it came into being ${ }^{16}$ (choosing to ignore the fact that even if in the world there only were the Ottoman Jews, who knew themselves to be a Jewish nation, they would have been entitled to an Ottoman successor state, let alone the fact that the demographic ratio of Jews and non-Jews in the territory later chopped out at Palestine, in late Ottoman times were comparable to the ratio of Muslims and others in the Indian subcontinent: would Sedley claim illegitimacy for Pakistan?), making it supposedly lawful to deny Jews or Israelis protections from what actually are savage delegitimisation campaigns, even violent attacks on Jews, on campuses and even (but then, is this not a tradition of Western civilisation at its rawest?) on the part of the clergy - at the cathedral at Piccadilly Circus (which Sedley 2007 defends). ${ }^{17}$ We are back to the archetype of hatred for Jews being fomented inside places of worship. When Sedley denies that a definition of antisemitism could legitimately refer to Jews' national self-determination rights, and when he says that many "Jews" disagree with the latter, he exploits a misnomer. Reneging upon Jewish identity does not give a renegade a right to deny Jews their rights (even though as early as the Middle Ages, the clergy would refer as "Jews" to converts from Judaism who attacked their former co-religionists, precisely for Sedley's purpose in identifying

15 He is getting forgetful. Canada? Australia? New Zealand? Finders, keepers. So it is not Britain that gobbled one third of Earth's lands out of imperial greed, but Israel? It is a role reversal (like the "Nazi Israel" slander). It also makes the Jew into the exceptional, uniquely guilty historical agent, like with the charge of deicide. His is a secular version. Also, notice this former senior judge's trick: he does away with the need for evidence and proof, by pushing his foregone conclusion upstream by giving it the status of an a priori premise, indeed an axiom.

16 Sedley mentions colonisation, as though there was a major Jewish component in the Ottoman Empire, or then in the part of it that after the British conquest became Mandatorial Palestine (in the latter, during the First World War the Jewish population decreased of 27\%, mainly owing to death by starvation because of the Allied sea blockade). If his criterion is the change in ethnic ratio, consider that locally tilted majorities had far-reaching consequences in Baghdad (which in 1920 only had a little more Shi' is than the large Jewish minority, but during the Baath period reduced Sunnis to a minority), and (in the 18 th and 20th centuries) in what is now Lebanon.

17 Of a speech given there by a Jewish-born professor on 27 June 2017 at that church, a Jewish observer present (Collier 2017b) reported about the climate that "The anti-Israel drumbeat is a one state drumbeat. 'From the river to the sea. When you empower it, whatever you may prefer, you empower those that seek the destruction of the State of Israel. [... As we left, the crowd had been suitably stirred up. We were told to put our 'jack boots on'. Those considered of identified as Zionist were insulted, heckled, threatened. The event had done its job”. 
as Jewish persons who are not other than by some ancestry or partial ancestry). Sedley's article (2017) is a milestone in the worsening of institutional antisemitism in Britain. He would rather say that his is an alarm against silencing of free speech, as there is no legal protection from being offended, nor should there be. ${ }^{18}$

\section{An onomastic cultural practice as a psychological mechanism of defence}

My onomastic point here is that even though distraught because of my own circumstances, upon my very first reading of Sedley (2017) - which was unlike my second reading, days later when I was calmer - I did not fail to notice that if one pronounces Sedley as zédli, then in Hebrew it means "a wicked scheming one, to me" (I dearly hope this is not true of the particular referent). This is precisely a Midrashic Name Derivation, as known from my cultural tradition. The formulaic pattern "Do not read X, but [rather] $\mathrm{Z}$ ", where $\mathrm{X}$ and $\mathrm{Z}$ are words that sound or are spelled similarly, is a frequent device in rabbinic wordplay, including in onomastic wordplay. (The noun zed in the singular occurs in Proverbs 21:24, where the referent is also yahir, 'haughty'. Zedim in the plural occurs, e.g., in Psalms 86:14: "O God, zedim have risen against me"; Psalms 119:69: "They attached a lie to me, zedim"; Psalms 119:85: "Zedim have dug ditches for me [to fall in]"; Psalms 119:122: "Let zedim not oppress me"; Psalms 19:14: "Also from zedim spare Thy servant"; Isaiah 13:11: "And I shall bring about the cessation of the pride of zedim".) [After listening to Moses' account of the Ten Plagues and the Exodus, his visiting fatherin-law, Jethro the Midianite, states: "Because by the [very] thing they [Pharaoh's and his subordinates] zádu (had schemed wickedly) against them [the Children of Israel]", traditionally interpreted in the sense that the pursuers having drowned after the Parting of the Sea was retribution in kind, or poetic justice (cf. Nissan 2014b), for the drowning of the babies or toddlers in the Nile as ordered by Pharaoh at the time Moses was born.]

An employment tribunal of three adjudicators presided by another magistrate, Anthony Snelson, right before Passover in 2013 gave a verdict in Fraser $v$ UCU (with a long motivation in practice adopting arguments used by Sedley, but also claiming it permissible to seek the end of the State of Israel) fully favouring the lecturers' trade union against a Jewish lecturer who wept in court while giving evidence, and dismissing a massive amount of incidents of claimed anti-Semitism as not qualifying as such, with the same tribunal also claiming that the applicant having taken his case to court as a waste of time for the court. ${ }^{19}$

18 Defamation and hate speech and their effects in what has been called "the war of a million cuts" (Gerstenfeld 2015) are, ex silentio, of no concern to Sedley (2017), or am I rather to say that he does not consider the indictment untruthful, and that he considers "the war of a million cuts" legitimate (albeit he does not use that descriptor).

19 The court in Fraser $v$ UCU only recognised one episode as being antisemitic, but it was precisely an episode it ruled it was too old an episode to adjudicate about. One thing that stands out in the tribunal's stated motivation is the alacrity at dodging the statutes, the clear-cut law of the land, in order to deny the Jewish applicant the protection he requested. The motivation also postured as though the outpouring of hatred to which Jews reacted and the Jewish 
Fraser $v$ UCU, too, was a milestone in the deterioration of the Jews' status in Britain. And more overtly than Sedley (2017), the tribunal's motivation in Fraser $v U C U$ is (under a veneer of punctilious correctness) breathtakingly supremacist, unabashedly enmeshed in both self-righteousness as well as assumptions about what is proper for Britons of the country's internal hegemonic identity to do to the rest of humankind. Unfortunately, such assumptions are entertained by part of the public, as British society in part has not grown out of the imperial past. It is not only a problem for nations such as Israel, nations that had enfranchised themselves from British rule, or other nations as well. It is also a big problem for Britain's own interests in international relations. There are so many good people in Britain who do not deserve the predictable effects of the ignoble behaviour of several influential denizens.

In Hebrew, sone 'hater' is the old term for 'antisemite', and - I am stating that much for the sake of the overall argument of the present study into cultural practices affecting onomastics and wordplay - the name Snelson is amenable to playful interpretation as sone l-sone, i.e., "hater to hater", alluding to the deliberations between the three members of that court. Besides, the name Snelson is homiletically amenable to a biblical verse, Psalms 58:9, which claims that the wicked ones move around like a snail that melts while proceeding. The reference is to the impact of the wickedness of the wicked ones: a snail leaves a path of mucus wherever it passes. And indeed, Fraser $v$ UCU is thus far the lowest point a 21 st-century U.K. court has reached, in race relations. And what Sedley (2017), who (whatever the reason) never mentions that case, has done, is offering a befitting doctrine to the judiciary.

The cultural practice of resemanticising name-manipulation has been documented and discussed by Ghil'ad Zuckermann in his 2006 article "Etymythological Othering' and the Power of 'Lexical Engineering' in Judaism, Islam and Christianity”. As exemplified in my present section, this onomastic practice, which has a long tradition in Jewish culture(s) throughout history, can still be psychologically poignant, in that it has a consolatory function as a display of vicarious empowerment even in what are sometimes otherwise dispiriting situations of powerlessness. In Jewish tradition, this has long used to be reflected in the trope that Esau's strength is in his sword, and Jacob's, in his tongue, and the sense traditionally intended is that Jews' power usually is prayer the highest authority conceivable. ${ }^{20}$

response were an equal political match. Several Jewish legal professionals analysed the ruling. It was pointed out, e.g., by the writer Howard Jacobson, that the same magistrate, Snelson, had instead applied in at least another case the very provision in the statutes he feigned to ignore in the motivation of Fraser $v$ UCU.

20 On the other hand, when some quarters in circles yielding societal power cause the dominant society to abase itself becoming oppressive and then persecutory (such transitions in behaviour being often oiled, so to speak, by spurious misrepresentations that are mainly conveyed through language, and intend and do eventually provoke actual or symbolic violence through the use of physical or otherwise societal power), such groups that know themselves to be unjustly oppressed find some strength in the knowledge of their own moral superiority. This has often been a Jewish experience. But in my lifetime I have observed time and again how the experience of those who are both insiders and outsiders in a society, typically minorities, is 
The resemanticising acrobacies of onomastic interpretation, when made to convey a moral judgement, are a cultural weapon. (This can also be observed in the unfortunate phenomenon of inferiorising nicknames, which fetter a victim to a despise role.) They are a cultural weapon, because they tell bearers of a name who they are. Or at the very least, for example when doing the latter would be socially unsafe, an in-group partakes of the discovered knowledge of the identity of the name-bearer, as disclosed by the name itself, if interpreted through a knowledgeable procedure. This conjures up ideas that probably have been with us humans since the earliest times of language and naming: namely, the idea that the name is the being, and the idea that knowing and using a name wields some power over the one named. ${ }^{21}$

double-edged: when a society is determined not to amend its ways, then the feedback of minorities is considered a threat; when instead a society is sincerely keen on being a just society, then that feedback is invaluable and indeed precious.

21 One of the arguments Sedley (2017) makes, namely, the argument that the law neither does, nor should, protect from being offended, is a thankless argument to make, as it paints the one making it into the corner of having to gracefully submit to a test of being grievously offended, yet not seeking legal remedy, on pain of being held a cheat (whereas not seeking it is not a sufficient condition for being cleared of the suspicion of being a cheat). In the case at hand, is the argument $a d h o c$ ? Was it made just so that Jews, and only Jews, must submit to indignities? I take no pleasure in administering the test, all the more so to an old man, and all the more for a man who, I suspect, was misled into errors of fact by his drive to protect free speech. I nevertheless proceed, as Sedley (2017) as it stands (errors of fact and all) is a very dangerous doctrine. I begin by pre-empting a foreseeable objection: a way to circumvent the implied promise not to seek legal remedy would be to claim that apart from "being offended", the act of causing offence also has other effects, which are actionable. In the case at hand, it would be easy to show such a claim about actionable ramifications to be spurious, because any effect is fully within the boundaries of the kind of causing offence as resulting in "being offended" as Sedley (2017) declares permissible and without legal protection, whereas the kind of incitement to which most Jews object or can be expected to object, and for which Sedley's doctrine (2017) claims impunity can ostensibly be shown to both being amenable to, and have already had, various effects that conspicuously transgress upon the statutes. This includes illegal effects, including life-changing effects, that I have experienced grievously myself because of British nonchalance with racism, or even because of British vocal quarters declaring the particular kind of racism a virtue indeed.

Now, the test. I suppose that on onomastic grounds, just as the surname lends itself to so apt a "midrashic" punning interpretation, something similar could be done with the first name, Stephen, but crucially, it must be done in the given prosopographical context. Moreover, the cultural references ought to be differently ascribed according to the style in which the pun is packaged. By one option, one may adopt a midrashic styleme, plug in the data (in this case, the first name), and state: "Read thou not Stivan, but rather Stiffen", then resort to yet another styleme which to express Nomen omen, "So called because of his end". Of a particular Hasmonean king, John Hyrcanus, it is related that he was righteous until old age, when he turned wicked. Likewise in the case at hand, in exceedingly old age the name-bearer did what he did to the Jews (i.e., Sedley 2017). This is a concatenation of narrative stock devices and stylemes from the aggadic midrash genre, but it obviously differs in that it mock-explicates a proper name within English 
(where stiffen suggests rigor mortis, so the pun is very offensive indeed, unacceptable were it not for the permissibility Sir Stephen's article proclaimed).

An alternative packaging for the pun would detect more modern cultural Jewish references: "I am a foreign born and bred Jew, so I am entitled if not expected to pronounce Stiffen". The references are two: to the experience of immigrants to England (and quite possibly, to the pronunciation of Sir Stephen's own paternal grandparents), and to a role reversal found on the very first page of Gerson Rosenzweig's 1892 satire in rabbinic Hebrew, Tractate America, a social critique of immigrant Jewish life in New York (Rosenzweig himself was a recent immigrant). As I have shown elsewhere (Nissan 2013b), in the given passage Rosenzweig was parroting antiimmigrant opinion as voiced by New York newspapers and cartoons, but turned this against the racist opinionists and their acolytes. As I mentioned, context is paramount, as application is ad personam; the same names could generally speaking be interpreted differently, even complimentarily, should the need arise. In the context of administering Sir Stephen the test his argument implicitly calls for, even the title Sir is amenable to the cultural practice of tendentious interpretation: since when he was knighted by Queen Victoria (for whom he was an avuncular character in her entourage), Sir Moses Montefiore has up to the present day been referred to, in Hebrew, as hassár Montefiore, where sar [sar] <śr> is used in the sense 'Sir', but in Biblical Hebrew and pre-modern Hebrew means 'nobleman' (in Israeli Hebrew, it means 'government minister'). But Sir can conceivably be approximated as well as [sir] <syr >, the noun for 'pot' and (when part of a compound 'sir of night') 'chamber-pot', which can be mischievously be claimed to be apt, the sense being 'sir of knight' indeed. (For sure, the potential for punning is not limited to Hebrew. In Italian, a rather quaint way to refer to a British peer is milordo, rather than pari d'Inghilterra or lord. But in Italian, mi lordo means 'I shit myself'. Sorry. As for bilingual punning: a future Austrian emperor reported that having gone to meet his brother-in-law, King Ferdinand IV of Naples, he found the latter was running after some courtiers and was holding a chamber-pot. Perhaps he wanted to Sir-ify them, and they were too shy to accept such honour?) It would be splendid if ceremonial were to be enriched: let the invitation for one to come and be knighted be given by a trumpeter and an usher exclaiming: "Be knighted!"

[As for Sir as a form of address, for which a knighthood is not a requisite, consider this item from Manwel Mifsud's Loan Verbs in Maltese (1994). Arabic and Hebrew, at least as close siblings as German and English are, share a great difficulty if a non-Semitic loanword has to be a verb, but the modern strata of both languages are sporadically able to come up with an ingenuous solution in specific verbs. Maltese, an Arabic "peripheral” dialect with much loosened grammatical constraints of word-formation (and whose speaking community being Catholic, so not impelled by noblesse oblige to abide by the prestigious linguistic model of the Qur'ann), finds it easy instead to form verbs out of Romance or English words. On one occasion, a teacher was irked with a pupil who kept addressing him as Sir, so he rebuked the boy for his invading manners. Where Cicero addressed Catilina with Usque tandem, the teacher instead said: "Int se ddum isserser?", i.e., "How long will you call out: Sir! Sir!?” (Mifsud 1994: 77), which I interpret word by word as: “Thou hour/now/in-future shalt-persist Sir!Sir!-ing?” He was reduplicating in the ad hoc coinage the English vocative Sir! May I add that that Maltese coinage reduplicating Sir! - a verbal form that in Arabic would be tasársir (dialectally tsársər) - adds a new lexeme to such an extant Arabic verb, which denotes 'to behave like a cad', and whose etymon is sársari 'cad' (Persian sarsarí). In Hebrew, sarsúr 'middleman' (cf. Arabic simsar, both from Middle Persian sapsar. Cf. Hebrew safsár 'broker' or 'speculator'. And cf., from Arabic simsar, Italian sensale 'middleman', whence Maltese derived a verb sánsal). But in Hebrew, "a sarsúr for sin” in rabbinic 
Hebrew denotes a pimp. (Cf. in ancient Rome, proxeneta 'matchmaker' or 'intermediary trying to bring about peace in family conflicts', but in French proxenète 'pimp') In the medieval book of homiletic exegesis (but based upon late antique material), Midrash Tanhuma, at the pericope Vayyiqra (the first of Leviticus), \$6, illustrations are provided for “The place of judgement, wickedness is there" (Ecclesiastes 3:16), about deliberate injustice meted out by appointed guardians and dispensers of justice, and then for Jeremiah 29:22, about two false prophets who, legend has it, "did not abandon their trade while in Babylon, and where měsarsěrín (pimping) to each other in transgressions", such as A trying to "prophetically" convince Nebuchadnezzar's wife to accept B as a lover, and B returning A the favour. This reduplicated verbal form befits them: Sirs both of them. Or rather, sires both of them: they each told the First Lady that she needed be impregnated by the other one, so she would give birth to little prophets. She replied: "I must consult my husband". Nebuchadnezzar told them he would test them in the Fiery Furnace like those three youths (Daniel's companions from Ch. 3 of Daniel; in Leviticus Rabbah 33:6, those three subject Nebuchadnezzar to cruel wordplay on his name: see Nissan 2014e); should the two prophets also survive, he and his wife would comply. They retorted: "But there were three of them". "Choose a third one". They chose the high priest Joshua, hoping to be saved by means of a miracle he deserved. He was saved from the Fiery Furnace (on the evidence of Zechariah 3:2: calling him "a wood chip saved from the fire"). The two false prophets instead failed the test.]

Is this more offensive than Sedley's no-protection doctrine would allow? If so, how come he would not protect such a puerile divagation, but does staunchly protect rabble-rousers of proven violence and incitement?

Now, to dispel the sense of shock from such brazenness, consider this entry from a peculiar book, certainly written by British officials or agents in the service of a vassal king, Feisal I of Iraq: “ABDUL SATTAR EFFENDI. Now living in Kirkuk; held an appointment (tutorial) in the household of Sultan 'Abdul Hamid. Has travelled in Egypt. Venerable in appearance, possesses Turkish, Persian and Egyptian orders, but is in reality foolish and puerile. Considerably laughed at by Kirkuk society which considers him a senile buffoon." This entry, so kind to the biography, displays British imperial administration at its most gallant (Iraq was a protectorate until 1932). It appears on p. 7 in the booklet Personalities / Mosul, Arbil, Kirkuk, Sulaimani / and / Frontiers. / Note on Mosul Town. / Baghdad: / Printed at the Government Press / 1923. (On the top left corner of the front cover: "CONFIDENTIAL.") The book in scanned form was usefully posted online by the Institut Kurde (http://bnk.institutkurde.org/images/pdf/EBAPLUJGRV.pdf - accessed in May 2017). British authorship is made fairly obvious not only by the language, but also by a remark in the entry for the Nestorian notable Constantine Hindi Effendi (1923: 29): "Is intelligent and not without humour". Also note this jibe, not uncharacteristic of the British imperial mentality: "Not exempt from the avarice which is the notable character of his community". This would have shocked my own (Jewish) maternal grandfather, at one point the Iraqi military commander of Kirkuk; he had a lofty personality.

The surname Hindi of that Nestorian was, I suggest, because some recent ancestor had been trading in India (an activity that among Iraqis was especially frequent among Jews), with no relation to the town of Hindiyya in central Iraq. By coincidence, Indian troops were sent by the British into that town in the 1920s, during a tribal insurgency in the 1920s. Early one morning, Sikh troops entered Hindiyya. Their orders were to kill any assembled men. They entered the local synagogue, and killed all the men who were saying their morning prayers before going to work (the town's Jews had nothing to do with the insurgency). That Iraqi Jewish experience with British rule is related by an old man, in an anthology of oral records at the end of Jacob Mansour's 


\section{When the upper echelons give way}

In late June 2017, "The High Court has ruled that the government acted unlawfully in attempting to restrict the Israel boycott. The Palestine Solidarity Campaign (PSC) had brought the case over guidance issued by the Department for Communities and Local Government last September" (Sugarman 2017b). The case was over a section preventing "ethical divestment" in Israel or in firms doing business in Israel and therefore considered by boycotters to be accomplices. "The judge, Sir Ross Cranston, said this element of the guidance was beyond what was available under the statutory powers of the Communities and Local Government Secretary. Making his ruling on Thursday [22 June 2017] morning, the judge allowed an application for judicial review. He said the PSC and its supporters objected to guidance because it limited their ability to campaign on the boycott issue" (Sugarman 2017b).

$\mathrm{He}$ [the judge] noted that the government was "concerned that local government pension funds should not be involved in such political issues because of the mixed messages it might give abroad; because it might undermine community cohesion at home by legitimising antisemitic or racist attitudes and attacks - although it accepts that antiIsrael and pro-Palestinian campaigning is not in itself anti-Semitic.

But he added: "None of these matters are at issue in this judicial review.

"The conclusion reached in the judgment has nothing to do with the political merits of the claimants' or the Secretary of State's position on these matters".

The PSC [i.e., the Palestine Solidarity Campaign, chaired by Hugh Lanning] hailed the ruling as a "triumph" for the boycott movement. [... ]

The outcome of the High Court case did not attract wide notice in the press. The Jewish Chronicle of course did report about it (Sugarman 2017b). And yet, I maintain, 22 June 2017 is a day of mourning for the British unwritten constitution. The change

(1991) grammar of Baghdadi Judaeo-Arabic dialect, and the text in the dialect is accompanied by an English translation. In that case, the Jews murdered were collateral damage. Note that the Third Afghan War that erupted in 1919, after Gurkha troops acting upon the orders of general Dyer opened fire on a public assembly of Sikh people in Amritsar, Punjab, killed 379 civilians, and wounded some 1200 more. [When it comes to onomastics, note that during that war in Afghanistan, during General Crocker's attack on "the village of Dakka, some five miles across the border towards Jalalabad in the north-east", a summit was renamed after an English monument: "a summit quickly dubbed Stonehenge Ridge from the circle of stone slabs which formed a Moslem shrine" (Richards 2003: 161).] As for Gurkha troops at the orders of the British, some were deployed during the conquest of Iraq and Baghdad in early June 1941. I recall a Tel-Aviv daily newspaper I read in Milan in the 1970s, at a time when once in a week it regularly included two facing pages of shorter articles, whose layouts was in horizontal strips upon each other. One week, in the middle of an odd page, which being in Hebrew was on the left side, an article by an Iraqi-born scholar (there was a photograph of him standing) discussed the pogrom the British let happen, and he referred to a detail I found nowhere else (and unknown to a specialist I consulted): in one particular place, Gurkha troops saw that their British masters couldn't care less, so they joined in the pogrom just for fun. 
effected by judicial fiat is momentous, unless of the state's three powers, the judiciary counts little other than for paper (which part of the time, many in British society think anyway, including corporate perpetrators). Let is be quite clear: boycotters and other race discrimination perpetrators in the U.K. all along the 21st century found little or no obstacle in the rule of law, but Fraser v UCU [2013] and PSC v the Secretary of State for Communities and Local Government [2017] absolutely energise them. He/she/it who would boycott a national identity (my own) would most certainly perpetrate race discrimination against individuals, such as me. ${ }^{22}$

The High Court judge, well, the High Court judge was ensnared. A small step for a man, but a huge step for the unwritten British constitution: of the Trimurti consisting of the executive, the legislative, and the judiciary branches of the state, it was non else

22 That the ruling violates European law is true, but what does it matter, as the U.K. is leaving the European Union? The ruling delegates to local government the supposed right to segregate on the basis of race, and denies central government its right to prevent that. Undeclared yet widely practised apartheid is allowed to become locally overt. We now live in the pre-desegregation United States. A judge, mark this: a judge, not a professional politician, is to be thanked for that. It is extremely significant that sympathy to the claims of boycotters can be evinced from the 22 June 2017 ruling of a judge at the High Court. What is more, and I do not even remotely suspect Cranston of being aware of the legal precedent, he brought back a juridic state of affairs for which the particular brand of Europe's far rightists who extol "Tradition" ought to be thankful: the privilege de non tolerandi Judaeos was something of which a flurry of cities in Europe (including Milan, the city where I grew up) were at the time proud of, like spots on a leopard skin and inside a polity subjected to central government (typically, the Holy Roman Empire). Unwittingly, Cranston has allowed the closest approximation affordable under current statutes to that Continental ancient régime privilege of the cities, and it must be said that he stretched statutory provisions to an extent that deprives Britain's central government of the ability to chart and steer foreign policy or even to enforce European law (which forbids boycotting any country that is not officially boycotted by the European Union. But Britain is leaving the EU). Thus, some would say (and ought to say) that the ruling reduces the central government of what once upon a time was the British Empire, to the rank of a protectorate, inasmuch a protectorate is not allowed to control its foreign policy. That Cranston was incapable to see that non-British humankind can retaliate heavily if now, in post-imperial (and the throes of Brexit negotiations) British local government is made by him free to discriminate against those nations they abhor - or should I say, the one and only Devil nation (the Jewish one) in the historical psyche of this misty island - says something about this knighted man. It is a cultural flaw, possibly subliminal.

Even though for fifteen years boycotters in the U.K. have broken the law with relish, the representatives of such local councils who adopt the boycott (thus making the direct involvement of the British state quite obvious, which is why lately, quite belatedly, the British government has tried to stop them doing that: hence those local councils' case in court against the government) have clearly been self-conscious about being at the High Court. Getting the High Court to side with them, even though by ordering an appeal court to consider their case (without the High Court making otherwise a determination either way) is such a trophy, that those legal representatives have conspicuously tried to minimise and make anodyne what the local councils they represent have done and are going to do (as though it is none else that deciding where not to invest their pension funds). 
than the judiciary, at the top but one rung of the ladder of the hierarchy of courts of law, that brought it about. The ruling in late June 2017 made it a bleak month for both the judiciary and the British constitution, because arguably, by judicial fiat, the British state has legally become what the pre-desegregation U.S. were, where the local level decided whether to exclude or not on the basis of race. The U.K. government generic claim that if the local councils are allowed to boycott, this would be detrimental to international relations, was an understatement. ${ }^{23}$

It is telling that the strategy of the claimants - the local councils adopting the boycott - at the High Court was to make it appear as though the local councils would just apply the boycott to investments such as for pension funds. What mattered was to get a High Court judge ensnared and agree to refer the matter to a court of appeal, thus lending legitimacy to an enterprise that for almost two decades has been utterly contemptuous of the rule of law. How the mighty have fallen. I dearly wish to believe that if instead of a besuited barrister talking about letting local councils decide where not to invest pension funds (namely, in Israel-related firms), the High Court judge could clearly see, say, the kind of football hooligan racists who chant "we like it, we like it, we like it" while throwing a Black man out of the Paris metro, ${ }^{24}$ he would have been disinclined to side with them in court (or, say, to accept an invitation to the pub where they, patting his back, would chant "And he is a good fellow"). The organisation that brought and won the case has a horrid record as conspiracy-theorists. ${ }^{25}$

This being Britain, there always seems to be lurking the tacit received notion "not to worry, this is just the Jews' problem". It can be shown that, like at other times and places in history, it begins with the Jews, but does not end with them. British society is faced with huge problems, and there is no sign of even beginning to tackle some of some of them. The plague of antisemitism (the former prime minister David Cameron

23 For one thing, this constitutional change alone could be reason enough for negotiations on Brexit with the European Union not to continue, as it would be grounds for being thrown out of the EU. And secondly, during Kennedy's presidency in the U.S., considerations about the Cold War made it imperative to putting an end to racial segregation (Dudziak 1988), whereas the U.K. is now at a fateful turn in international relations, and yet the June 2017 High Court finding enables local parts of the state (local councils) to racially segregate.

${ }^{24}$ On 17 February 2015, a group of about 150 British football fans was on its way to a Champions League match of Chelsea against Paris Saint-Germain, and several of these were caught on camera on the Paris metro, while chanting "We're racist, we're racist, and that's the way we like it", while at the same time repeatedly pushing off the train a Black Parisian man who was trying to board it; in July 2015, at Stratford magistrates' Court, a few of the culprits were banned for three or five years from attending football matches, and of these, a man aged 50 who was banned for five years, was both a director with the Human Rights Forum of all things, and a former policeman. Clearly, this is a case of a person who knew quite well that he was engaged in incompatible, indeed opposite, behaviours, in the one case apparently for gain, and in the other for pleasure and in order to express the politics he actually espoused.

25 E.g., http://david-collier.com/wp-content/uploads/2017/02/170222_palestine_solidarity_campaign_report.pdf (accessed in May 2017). 
called it "cancer", which is how it works, and he was taunting the leader of the opposition) has been allowed to fester freely all along the 21st century, making inroads with respect to previous decades. That by the 2010s, increasingly high echelons of the judiciary have been handling this incompetently (I am charitably sparing other adjectives) shows the sheer depth of the British crisis.

\section{Local government unbridled: Dumbarton sets the pace}

Take, for example, in Scotland, West Dunbartonshire Regional Council (with 100,000 inhabitants). For years now, it has been banning Israeli-published books from its public libraries, the only country boycotted. (In Italy, the newspaper Il Foglio reported this with revulsion, on 26 May 2011 on p. 3, under the title "Biblioteche judenrein". Note that racism in Scotland is notoriously fierce, and often related to both ethnic and religious differences.)

As the London-based David Collier has shown (2017c), the group that promotes the campaign in Dumbarton and is helped by the council, is led and operated by members who also contribute or add "likes" to, or share, posts on out-and-out anti-Jewish conspiracy theory websites. ${ }^{26}$ And these wild-eyed individuals have been supported by local government in Dumbarton, Scotland. ${ }^{27}$ (Or is it Dumbertown?) ${ }^{28}$

26 These even claim that "Princess Diana was assassinated by the Mossad", "Isis leader 'AlBaghdadi' is Jewish Mossad agent 'Simon Elliot”, "Bibi [Netanyahu] a suspect in Charlie Hebdo massacre", "David Rockefeller planned and funded 9/11", "Mossad agent accidentally admits they did 7/7 London bombings", "25000 Ukrainian children organs harvested in Israel”, "Canadian police bust Jewish mob run pedophile ring”, “This is why all Iranians are 'terrorists' / A Central Bank the Rothschilds don't own".

27 Note the $n$ vs the $m$ in Dunbartonshire vs Dumbarton. The peculiarities of British toponomastics are sometimes much more breathtaking. In Devon, the name of the town whose name is spelled Woolfardisworthy is pronounced [wulsəri] or [ulsəri]. Nearby towns includes ones

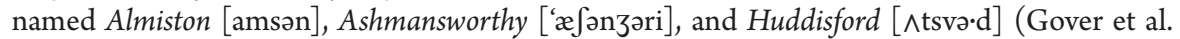
1969: 80-81). Again in Devon, there is a town whose name is spelled Hexworthy, but is pronounced [hæksəri] (Gover et al. 1969: 194). There is nearby a place called Laughter Hole or Laughter Tor, but the pronunciation is [la·tər]: "The first element may be a Celtic word corresponding to Welsh llethr, $\mathrm{Co}[\mathrm{rnish}]$ ledr, 'slope, cliff, declivity' with early attempts at folketymology. A possible further example of this name is found in Leather Tor infra 245" (Gover et al. 1969: 195). In Cumbria, the town name Waverton is pronounced [wa.rtən] (Armstrong et al. 1971 [1950]: 159), whereas the town name Sebergham is pronounced [sebrəm] or [sebərəm] and its earliest documented form is Setburg'ham, of 1204 (Armstrong et al. 1971 [1950]: 150). Burgh in the name of another Cumbrian town, Burgh by Sands, is pronounced [br^f] (Armstrong et al. 1971 [1950]: 126).

28 Etymological senses may be far from obvious, even when they superficially appear to be clear. Take the name of the town of Gossipgate, in Cumbria. It is recorded as Gossipesgate in 1279. The etymological sense is not *'gate where people stop to chat. "Gossip is used here in the sense of 'person with whom one has contracted spiritual affinity, according to canon law" (Armstrong et al. 1971 [1950]: 175, s.v. Gossipgate); where gossip or gossib 'God's sib' is similar to godfather and godmother, and where sib is related to its diminutive sibling. As for the element gate 
David Collier, having gone through the evidence of those individuals' involvement at websites, remarked: "It is a truly horrifying scenario. Almost every single person who is tagged into these images of Dumbarton activism, share hard-core antisemitic ideologies. Almost every single one" (Collier, 13 July 2017).

\section{A clearer picture of the steps of the technique of midrashic onomastic explication}

The "neo-midrashic" technique of onomastic manipulation is nowhere better illustrated than through another "example from real life" explained in this section. Namely, the elaboration of potential for resemantisation, and the latter's narrativisation, in the name of another of the dramatis personae of juridical legitimation of the onslaught on my group identity here in the U.K. Sir Ross Cranston gave the ruling denying central government the remit of preventing authorities of local government from adopting an international boycott. Let it be clear this section is a dispassionate, aseptic explanation of a technique, exemplified on a splendid onomastic example. ${ }^{29}$

In the respective onomastic case, options turn out to be multiple, and we can clearly see that the procedure can be conceived of as a cascading sequence: (a) choosing "despondent" as the value of the attitude (as opposed to, say, "endearing" or "celebratory"); (b) detecting phonosemantic matches in the lexicon of one or more target languages of the punning; (c) fitting these lexical items into a narrative trajectory joining them to the name bearer (nothing personal, Sir Ross!); (d) selecting an appropriate traditional styleme out the expressive and ideational repertoire of the midrashic corpus.

Had the input name been Russell, then, by applying as a constraint on the search the despondent mood, the search for phonosemantic matching (if the target language is Hebrew) yields $\sqrt{r s s}+E l$ in Hebrew, the lexical semantic concepts of the root and the noun being: 'shatter to fragments' + 'deity'. A conceptual constraint allows a or the deity/Deity to be the agent but not the direct object of that kind of action. This can be further narrativised in an optative mode as "Let the Deity shatter" the bearer into / rsisim/ 'small pieces of a broken whole'. (But the same lexical root $\sqrt{ }$ rss also possesses derivatives for 'shrapnel' and 'drops of dew', which in terms of conceivable situational contexts are staggeringly different.)

in Gossipgate, its sense in the latter is any of 'gate', or the sense of Old Norse gata 'road', or then (Armstrong et al. 1971 [1950]: 173, s.v. Bleagate): "Gate in this district appears usually to have the northern and north-midland dialect sense 'pasturage,' 'the right or privilege of pasturage for cattle”. Cf. Armstrong et al. (1952: 474, s.vv. Old Norse gata, and dialectal Middle English gate).

29 It is therefore nothing personal about Cranston the person or the factfinder. Just as he would not be drawn in his ruling into the merits of the calamitous case he had at hand, so I refuse to be further drawn in this study into the merits of that individual factfinder. At a workshop I attended in Camerino with legal scholars, judges, lawyers, and psychologists, they were not averse to the notion that a factfinder's contingent gastro-intestinal state is not necessarily uninfluential on his or her decision. 
Or, if the target language is Arabic, then the verb for 'to wash' matches Russell, but as the mood value set for the procedure is "despondent", this motivates selecting an item, from idiomatics, a verbal form in the future tense with an accusatival pronominal suffix, being the expletive for 'I'll wash him!' (where the idiomatics intends the direct object to be the corpse; i.e., the situation conjured up is being preparation for burial; so the implication is 'I'll outlive him!'). This is an expletive that, quite seldom, very angry speakers utter, ${ }^{30}$ and is understandably tabooed. Curiously, this is evocative of the highest kind of kindness in Judaism: preparing one for burial (including washing) and burying him or her is named 'favour and truth', i.e., a true favour, a favour not expected to be returned by the beneficiary.

But the input first name at hand is Ross. The word-form matches a singular masculine form of the imperative of a verbal conjugation derived from the Hebrew lexical root $\sqrt{ }$ rss. Would then the name-bearer be selected as the recipient of the imperative? In what other syntactic role could he befit? This of course depends upon the contingent constraints narrative trajectory pursued, in what in artificial intelligence would be called the search space. Yet another possibility is not to respect word boundaries: Sir Ross may yield as a fetched lexical item the root $\sqrt{ }$ srs of 'neutering' and even 'eunuch', or then some role associated in antiquity with Oriental courts and public administration that apparently only got the same name as 'eunuch' because in some polities in antiquity, the two concepts would have often been co-referential: some persons who were at court and were originally mainly remarkable for the effects of their anatomy and their being servants of the court, may have become appreciated enough for them to be entrusted with even some prestigious job in the service of the state.

Another option, which is instead quite relevant to the High Court ruling of 22 June 2017, is that central government has been emasculated (serús is the Hebrew action noun for this), so it is no longer capable of steering a course in international

30 This phono-semantic match works, provided that the $r$ is pronounced with the uvula, as a guttural rather than coronal rhotic consonant. Typically the rhotic is an uvular rhotic for Yiddish speakers, and the speakers of some Judeaeo-Arabic dialects (in words of Arabic stock rather than Hebrew or other stock), as well as most Israelis.

Interestingly, a picturesque description of responses to the 22 June 2017 ruling could be given in Arabic: one side, in this sketch, extols the judge (háda ar-Rasūl! "This is the man of the Providence"), but a Jewish response is negative instead (Baghdadi Judaeo-Arabic: 'aysalu! 'I'll wash him!" with an uvular trill). Both utterances are tabooed. In the case of arras, it is because "the Envoy" is preeminently the epithet of the founder of Islam. But the more general notion of "the man of the Providence" also exists.

In Italy, it is a notorious nugget of knowledge that Pius XI so described ("l'uomo della Provvidenza") the dictator Benito Mussolini, because they agreed the Concordat reconciling the Church to Italy, and setting up the sovereign City of the Vatican. It is by far not as well known that the same pope used that same descriptor also referring to Hitler, once they agreed a Concordat with Germany. But later, Pius XI died shortly before he could read out a speech he had prepared, condemning the Nazi racial doctrine. Pius XII did not rise to that level. 
politics. Horace wrote: ne sordida mappa corrūget nares, "let the dirty napkin not have you turn up your nose".

As for the surname Cranston (originally a toponym), given as input to the procedure, the options are as follows (the target language being Hebrew): (1) the lexical roots $\sqrt{q r n}+\sqrt{ } /$ ștn/ [stn], yielding (1.1) 'horn' ${ }^{31}+{ }^{2}$ Devil', ${ }^{32}$ and (1.2) 'ray of light ${ }^{33}+$ 'Devil', as well as (2) 'irradiate' + 'wholesale. ${ }^{34}$ In the next two steps, narrativisation and styling, one gets: (1.1), e.g., "Understand from this [or: It would appear one is to say], that a forefather of his was cuckolded $(<\text { horn })^{35}$ by the

31 In the Hebrew Bible, qéren 'horn' is also a symbol of strength. Cf. a somewhat similar metaphorical sense of Latin cornu 'horn': cornua addis pauperi (Horace), "you (o amphora of wine) add/give cockiness to the poor". Also in Middle French, corne may stand for "orgueil, force, puissance, fierté", as defined by Di Stefano (2015, Vol. 1:391, col. 3), and baisser les cornes stood for being humiliated (2015, Vol. 1: 392, col. 1).

32 If you reformulate the association of ideas in Latin, Cranston $\leftrightarrow$ cornua Satanae, then presumably some medieval or early modern Christian authors, familiar with the Etymologies of Isidore of Seville, would have been delighted with such elaborations. Bear in mind that on occasion, such matches would have passed for etymology.

Especially in Western civilisation, the Devil is imagined as being horned. One morning in the late 1990s, as my bus stopped at Woolwich Market, a young man wearing jeans got in and walked through the aisle, and people watched in astonishment and fearfully, as he had long, thick red horns attached to his forehead. Was he an actor on his way to a studio? Or was he making a lifestyle statement? People would have feared he embraced evil.

33 Michelangelo's statue Mosè features two horns on Moses' forefront, because of a misunderstanding of the Hebrew word for 'ray', which also means 'horn'. Pre-modern conceptions in optics maintained that rays of light protrude from objects and penetrate the eyes that see them.

34 Modern Hebrew / siṭon/ sitón or / sitonay/ sitonáy 'wholesaler', /siṭonut/ sitonút 'wholesale', from Mishnaic Hebrew siton (spelled sytwn) 'wholesale provision dealer', from Greek $\sigma i \tau \omega ́ v \eta \varsigma$. Cf. in Jewish Middle Aramaic sitona (spelled sytwn?) for either 'wholesale provision dealer', or 'frumentarius = commissary of the army'.

35 The idea is not Jewish. Informal Israeli Hebrew does possess /mqurnan/ mekurnán, a departicipial adjective for 'cuckolded', and at a lower register, there is hi 'astá lo karnáyim, 'she cuckolded him', but this is a loan idiom from European languages (and it is such also when one comes across it in spoken Arabic). There is a cost attached to resorting to the idiomatic sense 'cuckold/ed' of a derivative of the Hebrew lexical root for 'horn', because it does not belong to pre-modern strata of Hebrew. If you use present-day Hebrew in a neo-midrashic statement, the immediacy (appreciated by the average speaker) does not quite repay the more exigent recipient of the "quasi-literary" effort for the absence of the quaint patina one expects of midrashic texts.

There is some difference even among such European languages that do possess it, in the use of the 'horned' metaphor for 'cuckold'. When Arturo Toscanini was quite angry, he would shout at a player "Cornuto!" (and then: "here you go, you asked for it"), which is extremely transgressive, as it was to the man's face. Also notice the paramount difference between la Duchesse de Cornouailles and the mischievous *la Duchesse de Cornuailles.

In Middle French, horns, along with being a symbol for cuckoldry (Rabelais III.xiv: "Vous me semblez evidemment errer interpretant cornes pour cocuage”, cited by Di Stefano 2015, Vol. 1: 391, col. 3), also fitted in semantically different idiomatic usage. Being astonished was expressed, e.g., as found in the Cymbalum mundi IV.35: "de la quelle chose ilz sont aussi estonnez 
Devil”36 (but ideationally this is rather un-Jewish, and belongs much more to medieval early modern Western civilisation, e.g., as associated with the Malleus maleficarum, the 1486 inquisitorial textbook by the Dominicans Jacob Sprenger and Heinrich Kramer, a handbook of witch-hunts that set the pattern for 300 years), through a search of the solutions space in the domain of the situational repertoire; (1.2) "Just as Lucifer was shining prior to his fall, this one is shining in high rank prior to his fall" (again, whereas myths of the fallen angels were shared by Christianity and Judaism, shining Lucifer in particular only belongs to the former, based on a reference in Isaiah 14:12 to Heilel the Son of Dawn, who may have just been a politician); (2) "It foretells what befell (or: will befall) him (nomen omen; literally, 'al šem sofó, '[it is] after his end]'): ordinarily a person taking an X-ray scan receives a little radiation; but were his luck bad, he would receive qriná besitonút (wholesale radiation)" (an accidental massive overdose of radiation: a kind of incident that is unfortunately on record in recent decades among causes of death resulting from medical treatment). In example (2), the cultural distance from the traditional midrashic genre is in that the technique of radiography is hallmark of everyday life no earlier than the 20th century, and this also implies a need for modern terminology, ${ }^{37}$ whereas in examples (1.1) and (1.2) the distance was because of ideas borrowed from pre-modern non-Jewish Europe.

que si les cornes leur venoyent" (quoted by Di Stefano 2015: 392, col. 1). By à quatre cornes, one meant 'crazy' or 'extravagant', after the horns of a snail (Di Stefano 2015: 392). But (Di Stefano 2015: 393, col. 2) prendre quatre cornes en teste was a playful phrase denoting the act of donning the four-cornered hat of academics (les cornes). As for the snail (limace or limaçon, now escargot), a Lombard would supposedly flee when faced with one (Galien 3867: "Je ne suis pas Lombart, qui fuit pour la lymace”, quoted in Di Stefano 2015, Vol. 2: 964, col. 1), but in one text, a cuckold is addressed with "Lymasson, garde ta corne!" (quoted in Di Stefano 2015, Vol. 2: 964, col. 2).

In French and Italian, horns are a metaphor in naming what in English is called a two-finger salute. A post dated 3 April 2017 at Gilad Atzmon's website, widely considered antisemitic (www.gilad.co.uk), greeted the publication of Sir Stephen Sedley's unfortunate opinion (Sedley 2007) with "Official' UK anti-Semitism definition gets two-finger salute from legal experts" (http://www.gilad.co.uk/writings/2017/4/3/official-uk-anti-semitism-definition-gets-twofinger-salute-from-legal-experts - accessed in May 2017).

36 This does not ipso facto implicate a descendant: the naturalist Carl Linné spoke with a heavy regional accent, and his grandmother had been burnt at the stake as a witch, and yet Sweden gave him accolades and rewards. Note how misogyny shaped such ascriptions, but as early as Johann Wier's 1563 treatise, De praestigiis daemonum ac incantationibus, witches were being defended by claiming that whereas Satan deluded them, they were but old crazy women who could do nothing, and unlike magicians, were unaware of the nature of their actions (Valente 2006: 1176). Moreover, consider that as late as the 19th century, fierce clerical opposition to the Italian national movement went as far as claiming that Italian women patriots held lewd congress with the Devil.

37 Here again, at the level of linguistic formulation attentive to register and style, we are faced with the problem that one is grafting a modern item (here, from material culture) into a midrashic context. Are you to call X-ray as usual nowadays in Hebrew, qarnei Roentgen, or are you to rather concoct an archaistic 'aspaqlárya me'irá 'et 'atsmotáv šel adám, 'luminous mirror/ 
At any rate, one can see then - true to the dictum "Jacob's strength is in his mouth" (but the traditional sense is that Israel, i.e., Jews, pray: as they lack physical strength, their only strength is what they can achieve by verbal means, especially in having Providence intervene on their behalf) - that midrashic explication affecting names is a powerful rhetorical tool involving defamiliarisation, surprise, and vicarious confirmation of a telos or of a wish that the narrator and his audience feel is emotionally appropriate, in their collective Self's psychological self-defence. I have claimed elsewhere that midrashic explication of names is amenable to artificial intelligence modelling (a domain in which I have published and edited extensively). The examples at hand in this study show a form of Jewish cultural resistance and resilience. Is this madness? Madness judiciously employed is wisdom. In dire times of political powerlessness, traditional Jews (or at least some of their homiletes) were able to derive a sense of victory over those wronging them, by "conquering" their names. ${ }^{38}$

Or then, and this is perhaps the most authentic reconstruction of a traditional response earlier than the achievement of civil and political rights by the Jews (rights that more than once have been taken from them since, and further attempts are still ongoing): with no sense of achievement (let alone victory) at all, the lachrymose chronicler of old would have recorded the High Court ruling of 22 June 2017 by writing in Hebrew: "On 28 Sivan 5777, judge qr"n śț"n"? קר"ץ [transcribing both

screen that sheds light on a person's bones'? The latter circumlocution comes at the cost of lost immediacy. But an added decoding challenge produces pleasure for a reader who is game.

38 Perhaps the impact of such phono-semantic matches is stronger as there is a sense that they always were there, waiting to be discovered. Which is what the prolific mathematician Paul Erdős (1913-1996, in Hungarian Erdös Pál) - who left nearly 1,525 publications and had 511 collaborators - said about theorems. An agnostic, he nevertheless "spoke of 'The Book', a visualization of a book in which God had written down the best and most elegant proofs for mathematical theorems", and he begrudged Him for "keeping the most elegant mathematical proofs to Himself. When he saw a particularly beautiful mathematical proof he would exclaim, 'This one's from The Book!' This later inspired a book titled Proofs from the Book” (https://en.wikipedia. org/wiki/Paul_Erdős). His was the dictum "Another roof, another proof": "He would typically show up at a colleague's doorstep and announce 'my brain is open', staying long enough to collaborate on a few papers before moving on a few days later. In many cases, he would ask the current collaborator about whom to visit next” (https://en.wikipedia.org/wiki/Paul_Erdős).

39 That the transcription notates the two perceived parts of the compound in two words (which in the case at hand happen to match words from the Hebrew lexicon), and that the letter $\boldsymbol{w}$ is used in order to transcribe /s/, befits some notable pre-modern scriptorial usage of how to insert a foreign term in Hebrew text. " makes it stand out.

The reinterpretation as Hebrew words resembles how the Rashi (1040-1105) transcribed souris 'mouse' (in his days, the final $s$ was still pronounced) in the Old French compound calva souris 'bat' קאלב"א שורי"ץ (French chauve souris, the etymological sense being 'skull mouse', because of the ugly face of bats). As I explained in Nissan (2015, Sec. 3.2), because of medieval northern France's phonetics of Hebrew consonants, Rashi had the choice of rendering $s$ with any of three different Hebrew letters: $0 / \mathrm{s} /, \boldsymbol{w}$ for the Hebrew historical phonemes /š/ and /ś/, and צ (whose end-of-word allograph is $\mathbf{\gamma}$ ) for /s./. Rashi wrote down souris as something 
Cranston and kéren Satan, 'horn of Satan'] stood up as an obstacle (satán) to the government of the Kingdom, lest they prevent our haters from inciting against us, and he put us in the hands of the 'ironim (Burgers) who seek evil for us". That something like that could be truthfully and precisely claimed (which it is), yet again, this time in the year 2017, provides confirmation to what one sometimes hears from Jews and nonJews alike: people are fed up with being "too" civilised, and are reverting to barbarity.

\section{Concluding remark}

We have considered present-day application of a rich and long-lived cultural practice of manipulating personal names (or other proper names) in relation to some circumstances of their bearers. This article has developed a complex example, of how members of a currently oppressed group resort to onomastic wordplay, as a form of cultural resistance and recovery of pride. Sometimes, such wordplay unfolds within the patterns of the early rabbinic homiletic tradition of onomastic interpretive wordplay.

\section{References}

Alderman, G. 2008. C of E Sanctioned Israel Hate: The Use of an Anglican Church for This AntiIsrael Bile Was a Disgrace. Jewish Chronicle (London), 4 December.

Armon, T. 2005. Antisemitic Trends: Economic Background. (In English, trans. by Z. Ofer.) In The History of the Jews in Romania, III: Between the Two World Wars. (Publications of the Goldstein-Goren Diaspora Research Center, Book 173. A Hebrew edition was published in 1996.), L. Rotman and R. Vago (eds.), 109-142. Tel Aviv: The Goldstein-Goren Diaspora Research Center, Tel Aviv University.

Armstrong, A.M., A. Mawer, F.M. Stenton, and B. Dickins. 1950 (repr. 1971). The Place-Names of Cumberland. Part I: Eskdale, Cumberland and Leath Wards. (English Place-Name Society, 20.) Cambridge, England: Cambridge University Press.

Armstrong, A.M., A. Mawer, F.M. Stenton, and B. Dickins. 1952. The Place-Names of Cumberland. Part III: Introduction, etc. (English Place-Name Society, 22.) Cambridge, England: Cambridge University Press.

Collier, D. 2017a. Stephen Sedley, FSOI and the PSC, Getting Antisemitism All Mixed Up. [London,] 1 May. http://david-collier.com/getting-antisemitism-sedley-upside/ (accessed in May 2017).

Collier, D. 2017b. Avi Shlaim, the Foolish Old Man and the Adoring Church. [London,] 28 June. http://david-collier.com/avi-shlaim-st-james-piccadilly/ (accessed in May 2017).

Collier, D. 2017c. Scottish Antisemites in Dumbarton Get to Throw a Public Party. [London,] 13 July. http://david-collier.com/dumbarton-antisemites-party/ (accessed in May 2017).

Di Stefano, G. 2015. Nouveau dictionnaire historique des locutions: ancien français, moyen français, Renaissance. 2 vols. Turnhout, Belgium: Brepols.

Dudziak, M.L. 1988. Desegregation as a Cold War Imperative. Stanford Law Review 41: 61-120.

I back-transcribe as šwryș, which very clearly would have reminded pre-modern readers of Hebrew šéres (שרץ) for 'swarming creature(s)' (invertebrates, but also reptiles and mice; cf. "mice and other small deer" in Shakespeare's King Lear, where deer in small deer has a general sense, 'animal', like its etymological cognate, German Tier), and of the Hebrew active participle šoréṣ (שורץ) for 'swarming. It is almost as though Rashi made an etymological statement. 
Gerstenfeld, M. 2015. The War of a Million Cuts: The Struggle Against the Delegitimization of Israel and the Jews, and the Growth of New Anti-Semitism. [English] Jerusalem: Jerusalem Center for Public Affairs (distrib. jcpa@netvision.net.il in Israel, and through Amazon elsewhere).

Gilman, S. 1984. Jews and Mental Illness: Medical Metaphors, Anti-Semitism and the Jewish Response. Journal of the History of the Behavioral Sciences 20: 150-159. Reprinted in his Disease and Representation: Images of Illness from Madness to AIDS. Ithaca, NY: Cornell University Press. (Also in Italian, Bologna: Il Mulino, 1993.)

Gover, J.E.B., A. Mawer, and F.M. Stenton. 1969. The Place-Names of Devon. Part I. (English Place-Name Society, 8.) Cambridge, England: Cambridge University Press.

Harrowitz, N. and B. Hyams (eds.). 1995. Jews and Gender: Responses to Otto Weininger. Philadelphia, Pennsylvania: Temple University Press.

Hen-Tov, J. 2012 [1974]. Communism and Zionism in Palestine during the British Mandate. New Brunswick, New Jersey: Transaction Publishers (with a new preface by I. Friedman). Originally, Schenkman Publishing Company, 1974.

Jacobson, H. 2010. The Finkler Question. [Novel.] London: Bloomsbury.

Julius, A. 2010. Trials of the Diaspora: A History of Anti-Semitism in England. Oxford: Oxford University Press.

Lappin, S. 2009. Therapists to the Jews: Psychologizing the 'Jewish Question'. normblog, The weblog of Norman Geras, May 18, 2009. http://normblog.typepad.com/ normblog/2009/05/therapists-to-the-jews-psychologizing-the-jewish-question-by-shalom-lappin.html (accessed in May 2017).

Mansour, J. 1991. The Jewish Baghdadi Dialect [English]. Or-Yehuda, Israel: The Babylonian Jewry Heritage Center.

Mifsud, M. 1994. Loan Verbs in Maltese: A Descriptive and Comparative Study. (Studies in Semitic Languages and Linguistics, 21.) Leiden: Brill.

Moreshet, M. 1980. A Lexicon of the New Verbs in Tannaitic Hebrew [in Hebrew]. Ramat-Gan, Israel: Bar-Ilan University Press.

Nissan, E. 2012a. Asia at Both Ends: An Introduction to Etymythology, with a Response to Chapter 9. Chapter 10 in Burning Issues in Afro-Asiatic Linguistics, G. Zuckermann (ed.), 202387. Newcastle: Cambridge Scholars Publishing. [It is almost half the book. The table of contents of Ch. 10 is on pp. 12-13. The presentation of the book's Part II - the posthumous Ch. 9 by B. Bergman, and the response to it: Ch. 10 - and the two abstracts are on pp. 5-7. Biosketch on pp. 17-18.]

Nissan, E. 2012b. Legal Evidence, Police Investigation, Case Argumentation, and Computer Tools. 2 vols. (Law, Governance and Technology Series, 5.) Dordrecht, The Netherlands: Springer.

Nissan, E. 2013a. On a Few Categories of Personal Names Considered to Be Apt or Paradoxical. In Onomastics in the Contemporary Public Space, O. Felecan and A. Bugheşiu (eds.), 28-49. Newcastle: Cambridge Scholars Publishing.

Nissan, E. 2013b. Exploring Two Histories of American Political Cartoons. With a Digression: Late-19th-Century Treatments of the Theme "Immigrants from Europe's Gutters" as Conveyed Visually, vs. Its Mocking by Parroting in Immigrant Literature (Tractate America). International Studies in Humour 2(1): 178-244.

Nissan, E. 2014a. Nativised, Playfully Aetiologised Literary Zoonymy (3 parts). In Language, Culture, Computation: Essays Dedicated to Yaacov Choueka, Vol. 3: Computational Linguistics 
and Linguistics (LNCS, vol. 8003.), N. Dershowitz and E. Nissan (eds.), 593-611, 612-641, 642-779. Heidelberg \& Berlin: Springer-Verlag.

Nissan, E. 2014b. On the Principle of Retribution in Homiletics. Bibbia e Oriente 66(259-260261-262): 217-232.

Nissan, E. 2014c. On the Report of Isaac de Lattes Concerning the Death of the Apostate in Taormina. In Il bagno ebraico di Siracusa e la sacralità delle acque nelle culture mediterranee: atti del seminario di studio (Siracusa, 2-4 maggio 2011). (Machina Philosophorum: testi e studi dalle culture euromediterranee, 42.), G. Musotto e L. Pepi (eds.), 237-266 (+ abstract: 345-346). Palermo, Sicily: Officina di Studi Medievali.

Nissan, E. 2015. The Historical Record of Lexemes of the Same Word, and, in a Medieval Gloss, the Interplay of Etymological Perception with the Graphemic Surface of Words. Quaderni di Semantica 70 (new series, 1): 99-122.

Nissan, E. 2016. In the Garden and in the Ark: The belles lettres, Aetiological Tales, and Narrative Explanatory Trajectories. The Concept of an Architecture Combining Phono-Semantic Matching, and NLP Story-Generation. DSH: Digital Scholarship in the Humanities. doi: 10.1093/llc/fqw040 Advance Access published December 26, 2016. ${ }^{40}$

Nissan, E. and Y. HaCohen-Kerner. 2014a. The Design of the Phono-Semantic Matching (PSM) Module of the GALLURA Architecture for Generating Humorous Aetiological Tales. In Unconventional Anthroponyms: Formation Patterns and Discursive Function O. Felecan and D. Felecan (eds.), 496-508. Newcastle: Cambridge Scholars Publishing.

Nissan, E. and Y. HaCohen-Kerner. 2014b. GALLURA and the Challenge of Combining PhonoSemantic Matching with Story-Generation: Zoonomastic Illustration. In Language, Culture, Computation: Essays Dedicated to Yaacov Choueka, Vol. 3: Computational Linguistics and Linguistics. (LNCS, vol. 8003.), N. Dershowitz and E. Nissan (eds.), 780-866. Heidelberg \& Berlin: Springer-Verlag.

Nissan, E. and A.O. Shemesh. 2010. Saturnine Traits, Melancholia, and Related Conditions as Ascribed to Jews and Jewish Culture (and Jewish Responses) from Imperial Rome to High Modernity. Quaderni di Studi Indo-Mediterranei 3: 97-128.

Probst, S., A. Erdélyi, A. Moretto, and K. Chemla (eds.) 2005. Liberté et négation. Ceci n'est pas un festschrift pour Imre Toth. Paris. http://halshs.ccsd.cnrs.fr/halshs-00004274 (accessed in May 2017).

Richards, D.S. 2003. The Savage Frontier: A History of the Anglo-Afghan Wars. London: Pan Books. Previously, London: Macmillan, 1990.

Rose, J. 2005. The Question of Zion. Princeton, New Jersey: Princeton University Press.

Sedley, S. 2017. Defining Anti-Semitism. London Review of Books 39(9, 4 May): 8.

Sugarman, D. 2017a. Corbyn Appoints Anti-Israel Activist as Campaign Chief. Jewish Chronicle (London), 15 May. ${ }^{41}$

Sugarman, D. 2017b. High Court Rules Government Acted Unlawfully Over Restrincting Israel Boycott. Jewish Chronicle (London), 22 June. ${ }^{42}$

40 http://dsh.oxfordjournals.org/cgi/reprint/fqw040?ijkey=G8jetnWz4VqW9L3\&keyty pe $=$ ref (accessed in May 2017).

${ }^{41}$ https://www.thejc.com/news/uk-news/corbyn-appoints-anti-israel-activist-andrewmurray-as-campaign-chief-1.438501 (accessed in May 2017).

42 https://www.thejc.com/news/uk-news/high-court-rules-government-acted-unlawfully-over-restricting-israel-boycott-1.440406 (accessed in May 2017). 